\title{
Toxoplasma gondii among captive wild mammals in zoos in Brazil and Cuba: seroprevalence and associated risk factors
}

\author{
Toxoplasma gondii entre mamíferos silvestres cativos em zoológicos no Brasil e \\ em Cuba: soroprevalência e fatores de risco associados
}

Ginette Villar-Echarte1; Igor Falco Arruda'; Alynne da Silva Barbosa1,2; Raiden Grandía Guzmán; Anderson Mendes Augusto4; Fernando Troccoli4; Alejandro Manuel Rodríguez Segón5;

Ana Letícia Carvalho Santos; Paula Ferraz de Camargo Zanotto'; Mariana Zanchetta e Gava ${ }^{6}$; Hélio Langoni6; Maria Regina Reis Amendoeira ${ }^{1 *}$ (1)

\author{
${ }^{1}$ Laboratório de Toxoplasmose e outras Protozooses, Instituto Oswaldo Cruz - Fiocruz, Rio de Janeiro, RJ, Brasil \\ ${ }_{2}^{2}$ Departamento de Microbiologia e Parasitologia, Instituto Biomédico, Universidade Federal Fluminense - UFF, Niterói, RJ, Brasil \\ ${ }^{3}$ Centro para a Produção de Animais de Laboratório - CENPALAB, Havana, Cuba \\ ${ }^{4}$ Zoológico do Rio de Janeiro, Rio de Janeiro, RJ, Brasil \\ ${ }^{5}$ Parque Zoológico Nacional de Cuba, Havana, Cuba \\ ${ }^{6}$ Departamento de Higiene Veterinária e Saúde Pública, Faculdade de Veterinária e Zootecnia, Universidade Estadual Paulista - UNESP, \\ Botucatu, SP, Brasil
}

How to cite: Villar-Echarte G, Arruda IF, Barbosa AS, Guzmán RG, Augusto AM, Troccoli F, et al. Toxoplasma gondii among captive wild mammals in zoos in Brazil and Cuba: seroprevalence and associated risk factors. Braz J Vet Parasitol 2021; 30(2): e001921. https://doi.org/10.1590/S1984-29612021053

\begin{abstract}
Toxoplasma gondii is a zoonotic parasite of worldwide distribution that can infect several species of homeothermic animals. Few studies have evaluated the exposure of captive wild animals to T. gondii. This study involved a serological survey of anti-T. gondii antibodies in mammals kept in Cuba's National Zoo (PZN) and in the Rio de Janeiro Zoo (RIOZOO) in Brazil. The study consisted of a total of 231 serum samples from mammals, 108 from PZN and 123 from RIOZOO. All the samples were subjected to IgG anti-T. gondii testing by means of the inhibition ELISA method and the modified agglutination test, respectively. T. gondii antibodies were detected in $85.2 \%$ samples from PZN and 32.5\% samples from RIOZOO. At the PZN, Perissodactyla (92.3\%) was the order with the highest serological prevalence rate, whereas at the RIOZOO, the order Primates (46.7\%) stood out $(p<0.05)$. In addition to this association, the origin of the PZN animals was also associated with $T$. gondii infection. This finding demonstrates the need for constant veterinary monitoring of captive wild mammals in order to link the serological diagnosis with clinical alterations indicative of toxoplasmosis.
\end{abstract}

Keywords: toxoplasmosis, serology, zoo animals.

\begin{abstract}
Resumo
Toxoplasma gondii é um parasito zoonótico de distribuição mundial que pode infectar várias espécies de animais homeotérmicos. Poucos estudos avaliaram a exposição de animais silvestres em cativeiro ao T. gondii. Este estudo envolveu uma pesquisa sorológica de anticorpos anti-T. gondii em mamíferos mantidos no Zoológico Nacional de Cuba (PZN) e no Zoológico do Rio de Janeiro (RIOZOO) no Brasil. O estudo consistiu em um total de 231 amostras de soro de mamíferos, sendo 108 do PZN e 123 do RIOZOO. Todas as amostras foram submetidas à pesquisa de IgG anti-T. gondii pelos métodos de ELISA de inibição (PZN) e teste de aglutinação modificado (RIOZOO). Anticorpos de T. gondii foram detectados em 85,2\% das amostras do PZN e 32,5\% das amostras do RIOZOO. No PZN, Perissodactyla $(92,3 \%)$ foi a ordem com maior taxa de prevalência sorológica, enquanto no RIOZOO a ordem Primatas $(46,7 \%)$ se destacou $(p<0,05)$. Além dessa associação, a origem dos animais PZN também foi associada à infecção por T. gondii. Esse achado demonstra a necessidade de monitoramento veterinário constante de mamíferos silvestres em cativeiro, a fim de vincular o diagnóstico sorológico a alterações clínicas indicativas de toxoplasmose.
\end{abstract}

Palavras-chave: toxoplasmose, sorologia, animais de zoológicos. 


\section{Introduction}

Toxoplasmosis is a zoonotic disease of global distribution caused by the protozoan parasite Toxoplasma gondii. The definitive hosts of this parasite with its facultative heteroxenous life cycle are felids because they eliminate oocysts in their feces, while other mammals, including humans and birds, are their intermediate hosts (Amendoeira et al., 1999; Hill et al., 2005; Robert-Gangneux \& Dardé, 2012). This parasite is transmitted through the ingestion of tissue cysts contained in raw or undercooked meat, sporulated oocysts present in water and food contaminated by feline feces, or through the transplacental transmission of tachyzoites (Amendoeira, 1995; Tenter et al., 2000; Montoya \& Liesenfeld, 2004). In Brazil, the seroprevalence of $T$. gondii infection in the human population varies from 21.5 to 97.4\% (Souza et al., 2010; Dubey et al., 2012). Different species of wild mammals and birds can become infected with this protozoan parasite, including animals under human care in zoos. The exposure of wild mammals to T. gondii has been reported in serological surveys conducted in zoos in the United States, Mexico, China, Portugal, the Czech Republic and Spain, with prevalence rates ranging from 17\% to 57\% (de Camps et al., 2008; AlvaradoEsquivel et al., 2013; Luo et al., 2017; Tidy et al., 2017; Bártová et al., 2018; Cano-Terriza et al., 2019). In Brazil, serological surveys for $T$. gondii have already been carried out on mammals in zoos and farms in the states of Rio Grande do Norte, Paraíba, Pará and São Paulo, where positivity rates of 33 to $68 \%$ were detected (Minervino et al., 2010; Feitosa et al., 2017; Marujo et al., 2017).

It is known that the ex situ conservation of wildlife is one of the main functions of zoos (Aragão \& Kazama, 2013). Thus, studies that evaluate the exposure of mammals under different degrees of threat of extinction to the protozoan parasite $T$. gondii are essential. Among the different species of mammals, there are taxa that are known to present severe symptoms of toxoplasmosis, which may lead to fulminant death, particularly Neotropical primates (Bártová et al., 2018). In addition, members of the family Felidae, suffering from primoinfection, can contribute to the environmental contamination of zoos and their surroundings.

In view of the above, the primary objective of this study was to conduct a serological survey of different species of mammals kept under human care in a zoo located in Rio de Janeiro, Brazil and another in Havana, Cuba, in order to verify the positivity rates, as well as inherent risk factors for this protozoan infection.

\section{Materials and Methods}

\section{Ethical consideration}

This study was approved by the Ethics Committee on Animal Use of the Oswaldo Cruz Institute (CEUA-IOC) under Permit no. L-045/2016 and L-045/2016 A4. Approval for this study was also granted by the Biodiversity Authorization and Information System (SISBIO), Chico Mendes Institute for Biodiversity Conservation (ICMBio), under Protocol no. 54797-1.

\section{Study site and sampling}

The PZN covers an area of just over 3,460,000 $\mathrm{m}^{2}$ and houses more than 1500 animals, including birds, nonhuman primates, carnivores, ungulates, proboscids and reptiles. The RIOZOO covers an area of $138,000 \mathrm{~m}^{2}$ and houses more than 1300 animals, including birds, nonhuman primates, carnivores, ungulates, proboscids, reptiles and fish.

Blood samples were collected between April 2015 and June 2018, without disrupting zoo management routines in order to minimize stress in the animals, in the case of a one-time collection (one sample per individual). Of the total of 231 samples, 108 were from PZN (42 carnivores, 31 nonhuman primates, 22 cetartiodactyls and 13 perissodactyls) and 123 from RIOZOO ( 25 carnivores, 77 nonhuman primates and 21 cetartiodactyls). Tables 1 and 2 lists the animals from which blood samples were collected for this serological survey.

The sample number included in this study was a convenience, in which the samples were obtained from the Institutions' management routine. Thus, the animals were not subjected to new stress situations through capture and containment to carry out this study.

Blood samples were drawn by venipuncture of the jugular, cephalic, femoral or caudal vein, depending on the species, using 3 to $5 \mathrm{~mL}$ syringes and $25 \times 7 \mathrm{~mm}$ needles. The volume of blood collected corresponded to up to $1 \%$ of each animal's live weight. The samples were left at room temperature until clot formation (30 minutes). The separated serum was then drawn from the tubes, centrifuged at $1000 \mathrm{~g}$ for 10 minutes, transferred to sterile vials and stored at $-20^{\circ} \mathrm{C}$ until the time of laboratory analysis. 
Table 1. Animals of the order Primates involved in the serological survey.

\begin{tabular}{|c|c|c|c|c|c|}
\hline Order & Family & Species & PZN & RIOZOO & Total \\
\hline \multirow[t]{26}{*}{ Primates } & Aotidae & Aotus azarae & 0 & 3 & 3 \\
\hline & & Aotus nigriceps & 0 & 2 & 2 \\
\hline & Atelidae & Alouatta seniculus & 0 & 2 & 2 \\
\hline & & Ateles paniscus & 0 & 1 & 1 \\
\hline & Pitheciidae & Callicebus brunneus & 0 & 1 & 1 \\
\hline & & Chiropotes utahickae & 0 & 2 & 2 \\
\hline & & Pithecia irrorata & 0 & 4 & 4 \\
\hline & Cebidae & Cebus albifrons & 1 & 6 & 7 \\
\hline & & Cebus kaapori & 0 & 1 & 1 \\
\hline & & Sapajus apela & 2 & 12 & 14 \\
\hline & & Sapajus flavius & 0 & 6 & 6 \\
\hline & & Sapajus robustus & 0 & 6 & 6 \\
\hline & & $\begin{array}{c}\text { Sapajus } \\
\text { xanthosternos }\end{array}$ & 0 & 18 & 18 \\
\hline & Hominidae & Pan troglodytes & 4 & 0 & 4 \\
\hline & Cercopithecidae & $\begin{array}{l}\text { Chlorocebus } \\
\text { pygerythrus }\end{array}$ & 0 & 2 & 2 \\
\hline & & $\begin{array}{c}\text { Chlorocebus } \\
\text { sabaeus }\end{array}$ & 1 & 0 & 1 \\
\hline & & Macaca fascicularis & 4 & 2 & 6 \\
\hline & & Macaca fuscata & 0 & 1 & 1 \\
\hline & & Macaca mulatta & 7 & 1 & 8 \\
\hline & & Macaca nemestrina & 0 & 1 & 1 \\
\hline & & Mandrillus sphinx & 1 & 1 & 2 \\
\hline & & Papio anubis & 5 & 1 & 6 \\
\hline & & Papio cynocephalus & 0 & 1 & 1 \\
\hline & & Papio hamadryas & 6 & 2 & 8 \\
\hline & & Papio papio & 0 & 1 & 1 \\
\hline & & tal & 31 & 77 & 108 \\
\hline
\end{tabular}

\section{Serological analysis}

Serological testing by the inhibition ELISA method (ELISA/i) revealed anti-T. gondii antibodies in animals from PZN. Testing was carried out at the Toxoplasmosis Laboratory of Cuba's National Center for the Production of Laboratory Animals (CENPALAB), following the protocol proposed by Grandía et al. (2013), using polyclonal anti-T. gondii IgG conjugate. This method can be used for the serodiagnosis of $T$. gondii in any animal species. The test results were interpreted based on a sensory evaluation of the presence or absence of color. Thus, the intensity of the yellow color indicated the extent to which antibodies in the sample inhibited the binding of anti-T. gondii conjugate to the immobilized antigen on the plate. A negative reaction was characterized by an intense yellow color, which indicates that the anti-T. gondii conjugate has bound to the antigen due to the absence of specific antibodies in the sample. Conversely, a positive reaction was characterized by the absence of color, which indicates that binding of the anti-T. gondii conjugate to the antigen has been inhibited by the antibodies present in the sample. 
Table 2. Animals of the orders Carnivora, Cetartiodactyla and Perissodactyla involved in the serological survey.

\begin{tabular}{|c|c|c|c|c|c|}
\hline Order & Family & Species & PZN & RIOZOO & Total \\
\hline \multirow[t]{17}{*}{ Carnivora } & Canidae & Canis latrans & 1 & 0 & 1 \\
\hline & & Canis lupus & 1 & 0 & 1 \\
\hline & & Canis mesomelas & 1 & 0 & 1 \\
\hline & & Cerdocyon thous & 0 & 3 & 3 \\
\hline & & $\begin{array}{l}\text { Chrysocyon } \\
\text { brachyurus }\end{array}$ & 0 & 3 & 3 \\
\hline & Felidae & Leopardus pardalis & 0 & 2 & 2 \\
\hline & & Leopardus tigrinus & 0 & 3 & 3 \\
\hline & & Panthera leo & 18 & 3 & 21 \\
\hline & & Panthera onca & 0 & 1 & 1 \\
\hline & & $\begin{array}{c}\text { Panthera tigris } \\
\text { altaica }\end{array}$ & 0 & 1 & 1 \\
\hline & & Panthera tigris tigris & 1 & 2 & 3 \\
\hline & & Puma concolor & 2 & 2 & 4 \\
\hline & & Puma yagouaroundi & 0 & 1 & 1 \\
\hline & Hyaenidae & Crocuta crocuta & 3 & 0 & 3 \\
\hline & & Hyaena hyaena & 11 & 0 & 11 \\
\hline & Procyonidae & Nasua narica & 4 & 0 & 4 \\
\hline & & Nasua nasua & 0 & 4 & 4 \\
\hline \multirow[t]{12}{*}{ Cetartiodactyla } & Bovidae & Antilope cervicapra & 4 & 0 & 4 \\
\hline & & Bos taurus indicus & 2 & 0 & 2 \\
\hline & & Bos taurus watusi & 3 & 0 & 3 \\
\hline & & $\begin{array}{l}\text { Boselaphus } \\
\text { tragocamelus }\end{array}$ & 3 & 0 & 3 \\
\hline & & Oryx dammah & 1 & 0 & 1 \\
\hline & & Ovis orientalis & 3 & 0 & 3 \\
\hline & & Taurotragus oryx & 4 & 0 & 4 \\
\hline & Camelidae & $\begin{array}{c}\text { Camelus } \\
\text { dromedarius }\end{array}$ & 1 & 0 & 1 \\
\hline & Cervidae & Pecari tajacu & 0 & 9 & 9 \\
\hline & & Rusa unicolor & 0 & 11 & 11 \\
\hline & & Tayassu pecari & 0 & 1 & 1 \\
\hline & Giraffidae & $\begin{array}{c}\text { Giraffa } \\
\text { camelopardalis }\end{array}$ & 1 & 0 & 1 \\
\hline \multirow[t]{3}{*}{ Perissodactyla } & Equidae & Equus grevyi & 3 & 0 & 3 \\
\hline & & $\begin{array}{l}\text { Equus quagga } \\
\text { boehmi }\end{array}$ & 10 & 0 & 10 \\
\hline & \multicolumn{2}{|c|}{ Total } & 77 & 46 & 123 \\
\hline
\end{tabular}

The blood samples from the RIOZOO animals were subjected to the modified agglutination test (MAT), as proposed by Desmonts \& Remington (1980). The MAT was performed by the Laboratory of Zoonotic Disease Diagnostics at the Faculty of Veterinary Medicine and Animal Science, UNESP-Botucatu, Brazil. A titer of $\geq 1: 16$ was considered seropositive, as described by Marujo et al. (2017).

\section{Statistical analysis}

The data on each animal were analyzed according to the variables of order, sex, age group (young, juveniles or adults), permanence (years living in the zoo) $(1-5,6-10,>10)$ and origin (born or not in the zoo). Serological results 
and epidemiological variables were analyzed statistically using GraphPad Prism v. 5 software (https://graphpadprism.software.informer.com/5.0/). Absolute and relative frequencies were calculated, and the Chi-square or Fisher's exact test were applied to verify the association between the categorical variables of the two zoos, whose statistical significance was analyzed with a 95\% confidence interval.

To determine the magnitude of association of the analyzed variables, the odds ratio (OR) was calculated from contingency tables, as recommended by Pfeiffer (2002) in retrospective observational studies for those associated factors, according to the compare proportions test. The authors considered a variable with $O R>1$ as a risk factor and $\mathrm{OR}<1$ as a protection factor.

\section{Results}

Antibodies to T. gondii were detected in 92/108 (85.2\%) samples from PZN and 40/123 (32.5\%) samples from RIOZOO animals by ELISA/i and MAT, respectively.

An analysis of the taxa of the animals from which blood samples were collected revealed that the highest prevalence rate occurred in the order Perissodactyla (92.3\%), followed by Cetartiodactyla (90.9\%), Carnivora (88.1\%) and Primates (76.6\%) in PZN (Table 3). Of the 23 seropositive animal species in PZN, Panthera leo, Hyaena hyaena and Equus quagga boehmi were the ones that presented the highest prevalence of anti-T. gondii antibodies (Table 4).

Table 3. Comparison of proportions of seropositive animals analyzed in PZN and RIOZOO as a function of the different variables.

\begin{tabular}{|c|c|c|c|c|c|c|c|c|c|}
\hline \multirow{2}{*}{\multicolumn{2}{|c|}{$\begin{array}{c}\text { Variables } \\
\text { Total }\end{array}$}} & \multicolumn{4}{|c|}{ PZN } & \multicolumn{4}{|c|}{ RIOZOO } \\
\hline & & \multirow{2}{*}{$\begin{array}{c}\text { Positive } \\
30\end{array}$} & \multirow{2}{*}{$\begin{array}{l}\% \\
23\end{array}$} & \multirow{2}{*}{$\frac{\text { p value }}{76.6}$} & \multirow{2}{*}{$\begin{array}{c}\text { Total } \\
0.3632\end{array}$} & \multirow{2}{*}{$\begin{array}{c}\text { Positive } \\
77\end{array}$} & \multirow{2}{*}{$\begin{array}{l}\% \\
36\end{array}$} & \multicolumn{2}{|l|}{$p$ value } \\
\hline Order & Primates & & & & & & & 46.7 & $<0.0001$ \\
\hline & Carnivora & 42 & 37 & 88.1 & & 25 & 1 & 4 & \\
\hline & Cetartiodactyla & 22 & 20 & 90.9 & & 21 & 3 & 14.3 & \\
\hline & Perissodactyla & 13 & 12 & 92.3 & & 0 & 0 & 0 & \\
\hline \multirow[t]{2}{*}{ Sex } & Male & 62 & 55 & 88.7 & 0.34 & 72 & 22 & 30.5 & 0.69 \\
\hline & Female & 45 & 37 & 82.2 & & 51 & 18 & 35.3 & \\
\hline \multirow[t]{3}{*}{ Age group } & Adults & 53 & 44 & 88.3 & 0.6 & 107 & 37 & 34.6 & 0.29 \\
\hline & Juveniles & 52 & 46 & 88.5 & & 12 & 3 & 25 & \\
\hline & Young & 2 & 2 & 100 & & 4 & 0 & 0 & \\
\hline \multirow{3}{*}{$\begin{array}{l}\text { Time in } \\
\text { the zoo } \\
\text { (years) }\end{array}$} & $1-5$ & 67 & 59 & 88.1 & 0.60 & 31 & 10 & 32.3 & 0.78 \\
\hline & $6-10$ & 21 & 18 & 85.7 & & 29 & 8 & 27.6 & \\
\hline & $>10$ & 19 & 15 & 78.9 & & 63 & 22 & 34.9 & \\
\hline \multirow{2}{*}{$\begin{array}{l}\text { Origin in } \\
\text { zoo }\end{array}$} & Yes & 103 & 91 & 88.3 & 0.008 & 62 & 23 & 37.1 & 0.39 \\
\hline & No & 4 & 1 & 25 & & 61 & 17 & 27.9 & \\
\hline
\end{tabular}

In RIOZOO, the highest seroprevalence occurred within the order Primates (46.7\%), followed by Cetartiodactyla (14.3\%) and Carnivora (4\%) (Table 3). In the order Primates, the Neotropical species belonging to the genus Sapajus stood out. As for MAT titrations of the RIOZOO samples, all the orders of animals except nonhuman primates presented a titer of only 1:16. In contrast, samples from the order Primates showed high anti-T. gondii antibody titers of up to 1:4096 (Table 4).

An analysis of the epidemiological variables in the data from the two zoos indicated that the only statistically significant factor associated with $T$. gondii infection $(p<0.05)$ was the origin of the animals, i.e., whether or not they were born in the PZN. Animals born at this zoo were 22.75 times (OR: 22.75 IC 95\%: 2.186 - 236.7) more likely to be seropositive for anti-T. gondii antibodies than individuals born in other places. In RIOZOO, only a comparison of the results obtained for the taxa showed a statistically significant difference $(p<0.05)$ (Table 3$)$. 
Table 4. Animals testing positive in ELISA/i (PZN) and MAT (RIOZOO) tests.

\begin{tabular}{|c|c|c|c|c|c|c|c|c|}
\hline \multirow{3}{*}{ Order } & \multirow{3}{*}{ Species } & \multirow{3}{*}{$\begin{array}{c}\text { PZN } \\
\text { ELISA/i } \\
\text { Positive }\end{array}$} & \multicolumn{6}{|c|}{ RIOZOO } \\
\hline & & & \multicolumn{6}{|c|}{ MAT Titer } \\
\hline & & & Positive & 1:16 & 1:64 & 1:256 & 1:1024 & 1:4096 \\
\hline \multirow[t]{15}{*}{ Primates } & Alouatta seniculus & - & 2 & - & - & - & 1 & 1 \\
\hline & Aotus nigriceps & - & 1 & 1 & - & - & - & - \\
\hline & Ateles paniscus & - & 1 & 1 & - & - & - & - \\
\hline & Cebus albifrons & - & 3 & 2 & - & 1 & - & - \\
\hline & Cebus kaapori & - & 1 & 1 & - & - & - & - \\
\hline & Chiropotes utahickae & - & 1 & - & - & - & 1 & - \\
\hline & Macaca fuscata & - & 1 & - & - & 1 & - & - \\
\hline & Sapajus apella & - & 7 & 3 & 1 & 1 & 1 & 1 \\
\hline & Sapajus flavius & - & 3 & 1 & - & 1 & - & 1 \\
\hline & Sapajus robustus & - & 3 & - & - & 1 & 1 & 1 \\
\hline & Sapajus xanthosternos & - & 13 & 4 & 1 & 2 & 2 & 4 \\
\hline & Macaca mulatta & 7 & - & - & - & - & - & - \\
\hline & Pan troglodytes & 2 & - & - & - & - & - & - \\
\hline & Papio Anubis & 4 & - & - & - & - & - & - \\
\hline & Papio hamadryas & 4 & - & - & - & - & - & - \\
\hline \multirow[t]{9}{*}{ Carnivora } & Canis lupus & 1 & - & - & - & - & - & - \\
\hline & Canis mesomelas & 1 & - & - & - & - & - & - \\
\hline & Crocuta crocuta & 3 & - & - & - & - & - & - \\
\hline & Hyaena hyaena & 10 & - & - & - & - & - & - \\
\hline & Nasua narica & 2 & - & - & - & - & - & - \\
\hline & Leopardus pardalis & - & 1 & 1 & - & - & - & - \\
\hline & Panthera leo & 17 & - & - & - & - & - & - \\
\hline & Panthera tigris tigris & 1 & - & - & - & - & - & - \\
\hline & Puma concolor & 2 & - & - & - & - & - & - \\
\hline \multirow[t]{12}{*}{ Cetartiodactyla } & Antilope cervicapra & 4 & - & - & - & - & - & - \\
\hline & Bos taurus indicus & 2 & - & - & - & - & - & - \\
\hline & Bos taurus watusi & 3 & - & - & - & - & - & - \\
\hline & Boselaphus tragocamelus & 3 & - & - & - & - & - & - \\
\hline & Camelus dromedaries & 1 & - & - & - & - & - & - \\
\hline & Giraffa camelopardalis reticulata & 1 & - & - & - & - & - & - \\
\hline & Oryx dammah & 1 & - & - & - & - & - & - \\
\hline & Ovis orientalis orientalis & 3 & - & - & - & - & - & - \\
\hline & Taurotragus oryx & 2 & - & - & - & - & - & - \\
\hline & Tayassu pecari & - & 1 & 1 & - & - & - & - \\
\hline & Pecari tajacu & - & 1 & 1 & - & - & - & - \\
\hline & Rusa unicolor & - & 1 & 1 & - & - & - & - \\
\hline \multirow[t]{2}{*}{ Perissodactyla } & Equus quagga boehmi & 9 & - & - & - & - & - & - \\
\hline & Equus grevyi & 3 & - & - & - & - & - & - \\
\hline
\end{tabular}




\section{Discussion}

In general, seropositivity rate for $T$. gondii detected among the captive mammals was $85.2 \%$ at PZN, according to the ELISA/i and $32.5 \%$ at RIOZOO, according to the MAT. Seropositivity rates lower than PZN and higher than RIOZOO were detected in animals of different taxonomic orders kept in zoos in Mexico (53.3\%), Northern Portugal (57.1\%), and Spain (42\%) using the MAT, and in the Czech Republic (33\%) using the latex agglutination test (LAT) (Alvarado-Esquivel et al., 2013; Tidy et al., 2017; Bártová et al., 2018; Cano-Terriza et al., 2019). However, prevalence rates lower than those found in this study have been detected by the indirect hemagglutination (IHA) test among captive animals living in zoos in China (17.9\%) (Luo et al., 2017).

The serological results for $T$. gondii in wild animals kept in other zoos in Brazil revealed higher seropositivity rates detected by the MAT among mammals in the zoo in Sorocaba/São Paulo (40.5\%), Pará and Rio Grande do Norte (57.8\%) and João Pessoa/Paraíba (68.9\%) (Minervino et al., 2010; Feitosa et al., 2017; Marujo et al., 2017). Comparisons with other serological surveys involving captive animals at zoos in Cuba could not be made, since this is the first study that investigated anti-T. gondii antibodies in captive wild mammals in a zoo in that country. The difference in the general serological prevalence rates of anti-T. gondii antibodies identified in the aforementioned studies involving captive mammals from zoos and those detected at PZN and RIOZOO can be attributed to the diversity of species included in these studies, the variety of serological tests (sensitivity and specificity) used, the cut-off they adopted, and the intrinsic epidemiological scenario of each country, including differences in animal care management. Although comparisons of serological frequencies obtained between RIOZOO and other Brazilian zoos have been carried out, these should be analyzed with caution. Since the squad of Institutions such as Zoos, it is usually composed of wild animals of different species, which have different degrees of susceptibility to the protozoan. In addition, the different practices of health management of the squad, as well as the choice of the serological technique can have a different influence on the results obtained.

Although it is not the objective of this study to compare serological techniques, it is important to note that the choice of these occurred according to the technology and human resources available in the research institutions. In addition, their foundation was a decisive factor in the choice of ELISA/i and MAT, as they can be used to search for IgG antibodies in several host species.

An analysis of the seroprevalence of anti-T. gondii antibodies as a function of the taxonomic order of the captive wild mammals included in this serological survey revealed that the orders Cetartiodactyla (90.9\%) and Perissodactyla (92.3\%) presented the highest seroprevalence rates in the PZN. A similar perspective was found in a survey carried out at zoos in the north of Portugal, where the order Cetartiodactyla showed the highest positivity among the sera of the analyzed mammals (Tidy et al., 2017). The higher positivity rates found among these orders of mammals may be attributed directly to their herbivorous feeding habit, suggesting that the forage or water supplied to these animals may be contaminated with $T$. gondii oocysts. It should be noted that, given that they are herbivores, they spend most of their time in paddocks ingesting large volumes of forage, increasing the possibility of ingesting $T$. gondii oocysts if their environment is contaminated by them. This finding is supported by the high seropositivity rate detected in Equus quagga boehmi, the species among the ungulates that presented the highest seropositivity rate at the PZN.

In addition to ungulates in the PZN, carnivores, particularly Panthera leo, showed a high prevalence of anti-T. gondii antibodies. High seroprevalence of anti- $T$. gondii antibodies among carnivores has also been reported in zoos in various countries, including the United States, Mexico, the Czech Republic and Spain (de Camps et al., 2008; AlvaradoEsquivel et al., 2013; Bártová et al., 2018; Gomez-Rios et al., 2019; Cano-Terriza et al., 2019). T. gondii infection may have been transmitted to carnivores by feeding them with carcasses and viscera contaminated with protozoan tissue cysts. In addition, they may have been infected through their predation of small wandering animals, which may have accidentally entered the enclosures of these animals, considering that many species of the order Carnivora at both zoos, especially felids, are predators at the top of the food chain. These carnivores may even have become infected prior to captivity or by drinking water contaminated with oocysts. It is noteworthy that lions in the PZN are kept in groups in large enclosures on bare ground. This makes it difficult to routinely remove feces from the environment, favoring the sporulation of $T$. gondii oocysts and environmental contamination, if any felid is in the latency period. Moreover, once these oocysts are in the environment, they can leach into the enclosures of other animals, spreading environmental contamination.

Among all the orders included in the serological survey in RIOZOO, the taxon that presented the highest frequency of exposure to $T$. gondii was the order Primates, and this positivity was significantly associated with infection. It was found that the Neotropical nonhuman primates of the family Cebidae, especially the genus Sapajus sp., 
corresponded to the largest sample among the evaluated primates. These results are compatible with other reports in Brazilian literature, since seropositivity for $T$. gondii has been described in different species of Neotropical primates, particularly among Sapajus sp. kept at different animal rescue centers and in zoos and breeding facilities in Brazil's north, northeast and southeast regions (Minervino et al., 2010; Pires et al., 2012; Ferreira et al., 2015; Feitosa et al., 2017; Marujo et al., 2017). However, the significant association between the order Primates and the seropositivity for anti-T. gondii antibodies observed in RIOZOO may be ascribed to the fact that the number of sampled individuals and diversity of species were numerically higher than those of other mammalian orders.

It is known that some species/genera of New World Primates are extremely susceptible to toxoplasmosis and that they are more vulnerable to this disease than Old World primates. According to Innes (1997), this susceptibility is based on the evolutionary hypothesis that these animals were isolated from felids due to their arboreal habit, and therefore from contact with protozoan oocysts, making them more susceptible to disease.

Among neotropical primates, there are three distinct susceptibility patterns to toxoplasmic infection, ranging from acute fulminant infections, severe or medium, to chronic infections (Epiphanio et al., 2003; Casagrande et al., 2013; de Paula et al., 2020). In this last group, the genera Sapajus and Cebus are included in the chronic infections, which in general, are asymptomatic presenting detectable levels of IgG anti-T. gondii antibodies (Bouer et al., 2010; Catão-Dias et al., 2013). The resistance profile of these neotropical primate taxa may have favored the sample shown in RIOZOO, since most of the animals included in this Institution were from the Cebidae Family, that is, those that are generally resistant to toxoplasmic infection.

In RIOZOO, nonhuman primates feed mainly on fruits and vegetables, which are routinely washed in tap water. Thus, the main sources of infection of these primates can be considered the poor hygiene of these foods, the water destined for washing them, and also their drinking water when contaminated with sporulated oocysts of the parasite. Although Neotropical primates have arboreal habits, their sporadic contact with the ground in their enclosures, probably contaminated with feces of wild felines in the zoo itself, as well as with feces of synanthropic domestic felines, may also have acted as a source of infection. Moreover, one cannot rule out the possibility that small birds and synanthropic mammals chronically infected with $T$. gondii accidentally entered the primates' enclosures and were preyed upon, transmitting the protozoan to the primates in this zoo.

An analysis of the frequency of mammals with anti-T. gondii antibodies at the two zoos of this survey indicated that sex, age group and length of stay in the enclosures of these zoos were not associated with infection. Similarly, no difference was found between sexes and age groups in serologically reactive captive mammals kept in zoos in Spain (Cano-Terriza et al., 2019). These findings demonstrate that the mammals of these institutions are also exposed to infection by this protozoan, regardless of sex and age group. However, the mammals born in the PZN showed a significantly higher seroprevalence than those born in other locations. Similarly to the findings of this study, animals born at the Sorocaba Zoo in the state of São Paulo were 2.1-fold more likely to have anti-T. gondii antibodies than wild animals captured in the natural environment (Marujo et al., 2017). Although the variable of origin in the PZN was considered a risk factor, this finding should be analyzed with caution, since there was no uniform distribution of the sampled mammals among the categories of this variable, emphasizing the need for further studies.

The findings of this study underscore the widespread exposure to T. gondii among the captive mammals of two zoos located in different countries of Latin America. This high exposure denotes the importance of improvements in sanitary management, including hygiene practices applied to food, enclosures, control of pests and stray animals, and fomites, including the regular change of clothing and shoes of zookeepers to prevent contamination between enclosures. Even so, the interruption of the transmission of this protozoan cannot be guaranteed, as T. gondii is a euryxenous protozoan that has different transmission routes. This underscores the need for constant veterinary monitoring of the animals in order to associate the serological diagnosis with clinical changes compatible with toxoplasmosis, especially in the most susceptible groups, as is the case of Neotropical primates. Thus, further studies of serological surveys associated with analyzes of epidemiological factors referring to sanitary management are essential to be carried out in captive wild animals in order to confirm possible transmission mechanisms.

\section{Acknowledgements}

The authors thank the Coordenação de Aperfeiçoamento de Pessoal de Nível Superior (CAPES) for financial support. 


\section{References}

Alvarado-Esquivel C, Gayosso-Dominguez EA, Villena I, DubeyJP. Seroprevalence of Toxoplasma gondii infection in captive mammals in three zoos in Mexico City, Mexico.J Zoo Wildl Med 2013; 44(3): 803-806. http://dx.doi.org/10.1638/2013-0032.1. PMid:24063119.

Amendoeira MRR, Costa T, Spalding SM. Toxoplasma gondii Nicolle \& Manceaux, 1909 (Apicomplexa: Sarcocystidae) e a Toxoplasmose. Rev Souza Marques 1999; 1(1): 15-35.

Amendoeira MRR. Mecanismos de transmissão da toxoplasmose. An Acad Nac Med 1995; 155(4): $224-225$.

Aragão GMO, Kazama R. A função dos zoológicos nos dias atuais condiz com a percepção dos visitantes? Educação Ambiental em Ação. 2013; 43: 1-4.

Bártová E, Lukášová R, Vodička R, Váhala J, Pavlačík L, Budíková M, et al. Epizootiological study on Toxoplasma gondii in zoo animals in the Czech Republic. Acta Trop 2018; 187: 222-228. http://dx.doi.org/10.1016/j.actatropica.2018.08.005. PMid:30096285.

Bouer A, Werther K, Machado RZ, Nakaghi ACH, Epiphanio S, Catão-Dias JL. Detection of anti-Toxoplasma gondii antibodies in experimentally and naturally infected non-human primates by Indirect Fluorescence Assay (IFA) and indirect ELISA. Rev Bras Parasito/ Vet 2010; 19(1): 26-31. http://dx.doi.org/10.1590/S1984-29612010000100006. PMid:20385056.

Cano-Terriza D, Almería S, Caballero-Gómez J, Díaz-Cao JM, Jiménez-Ruiz S, DubeyJP, et al. Serological survey of Toxoplasma gondii in captive nonhuman primates in zoos in Spain. Comp Immunol Microbiol Infect Dis 2019; 65: 54-57. http://dx.doi.org/10.1016/j. cimid.2019.04.002. PMid:31300126.

Casagrande RA, da Silva TCE, Pescador CA, Borelli V, Souza JC Jr, Souza ER, et al. Toxoplasmose em primatas neotropicais: estudo retrospectivo de sete casos. Pesq Vet Bras 2013; 33(1): 94-98. http://dx.doi.org/10.1590/S0100-736X2013000100017.

Catão-Dias JL, Epiphanio S, Kierulff MCM. Neotropical Primates and Their Susceptibility to Toxoplasma gondii: New Insights for an Old Problem. In: Brinkworth J, Pechenkina K, editors. Primates, pathogens, and evolution. developments in primatology: progress and prospects. New York, NY: Springer; 2013.p. 253-289. http://dx.doi.org/10.1007/978-1-4614-7181-3_9.

de Camps S, Dubey JP, Saville WJA. Seroepidemiology of Toxoplasma gondii in zoo animals in selected zoos in the midwestern United States. J Parasitol 2008; 94(3): 648-653. http://dx.doi.org/10.1645/GE-1453.1. PMid:18605803.

de Paula NF, Dutra KS, de Oliveira AR, dos Santos DO, Rocha CEV, Vitor RWA, et al. Host range and susceptibility to Toxoplasma gondii infection in captive neotropical and Old-world primates. J Med Primatol 2020; 49(4): 202-210. http://dx.doi.org/10.1111/ jmp.12470. PMid:32436219.

Desmonts G, Remington JS. Direct agglutination-test for diagnosis of Toxoplasma infection: method for increasing sensitivity and specificity. J Clin Microbiol 1980; 11(6): 562-568. http://dx.doi.org/10.1128/JCM.11.6.562-568.1980. PMid:7000807.

Dubey JP, Lago EG, Gennari SM, Su C, Jones JL. Toxoplasmosis in humans and animals in Brazil: high prevalence, high burden of disease, and epidemiology. Parasitology 2012; 139(11): 1375-1424. http://dx.doi.org/10.1017/S0031182012000765. PMid:22776427.

Epiphanio S, Sinhorini IL, Catão-Dias JL. Pathology of toxoplasmosis in captive new world primates. J Comp Patho/ 2003; 129(2-3): 196-204. http://dx.doi.org/10.1016/S0021-9975(03)00035-5. PMid:12921726.

Feitosa TF, Brasil AWL, Parentoni RN, Vilela VLR, Nety TFL, Pena HFJ. Anti-Toxoplasma gondii antibodies in mammals, birds and reptiles at the zoological-botanical park in João Pessoa, Paraíba, Brazil. Arq Inst Biol (Sao Paulo) 2017; 84: e0022016. http://dx.doi. org/10.1590/1808-1657000022016.

Ferreira DRA, Ribeiro VO, Laroque PO, Wagner PGC, Pinheiro Júnior JW, Silva JCR, et al. Risk factors associated with Toxop/asma gondii infection in captive Sapajus spp. Am J Primatol 2015; 77(5): 558-562. http://dx.doi.org/10.1002/ajp.22377. PMid:25676671.

Gomez-Rios A, Ortega-Pacheco A, Gutierrez-Blanco E, Acosta-Viana KY, Guzman-Marin E, Guiris-Andrade MD, et al. Toxoplasma gondii in Captive Wild Felids of Mexico: Its Frequency and Capability to Eliminate Oocysts. Vector Borne Zoonotic Dis 2019; 19(8): 619-624. http://dx.doi.org/10.1089/vbz.2018.2385. PMid:30615592.

Grandía GR, Entrena GA, Cruz HJ, Ginorio GD, Domenech Cl, Alfonso MA, et al. Validación de un sistema inmunoenzimático de inhibición para el diagnóstico de Toxoplasma gondii en Felis catus. Rev Electrón Vet 2013; 14(7): 1-17.

Hill DE, Chirukandoth S, Dubey JP. Biology and epidemiology of Toxoplasma gondii in man and animals. Anim Health Res Rev 2005; 6(1): 41-61. http://dx.doi.org/10.1079/AHR2005100. PMid:16164008.

Innes EA. Toxoplasmosis: comparative species susceptibility and host immune response. Comp Immunol Microbiol Infect Dis 1997; 20(2): 131-138. http://dx.doi.org/10.1016/S0147-9571(96)00038-0. PMid:9208198.

Luo H, Li K, Zhang H, Gan P, Shahzad M, Wu X, et al. Seroprevalence of Toxoplasma gondii infection in zoo and domestic animals in Jiangxi Province, China. Parasite 2017; 24: 7. http://dx.doi.org/10.1051/parasite/2017007. PMid:28224883.

Marujo RB, Langoni H, Ullmann LS, Pellizzaro M, Neto RND, Camossi LG, et al. Toxoplasma gondii antibodies and related risk factors in mammals at Sorocaba zoo, São Paulo, Brazil. Semina: Ciênc Agrár 2017;38(4 Suppl 1): 2845-2850. http://dx.doi. org/10.5433/1679-0359.2017v38n4SUPLp2845. 
Minervino AH, Soares HS, Barrêto-Júnior RA, Neves KAL, Pena HFJ, Ortolani EL, et al. Seroprevalence of Toxoplasma gondii antibodies in captive wild mammals and birds in Brazil. J Zoo Wildl Med 2010; 41(3): 572-5744. http://dx.doi.org/10.1638/20100046.1. PMid:20945665.

Montoya JG, Liesenfeld O. Toxoplasmosis. Lancet 2004; 363(9425): 1965-1976. http://dx.doi.org/10.1016/S0140-6736(04)16412-X. PMid:15194258.

Pfeiffer DU. Analytic epidemiology. In: Pfeiffer DU. Veterinary epidemiology - an introduction. London, UK: University of London, Epidemiology Division Department of Veterinary Clinical Sciences; 2002. p. 18-27.

Pires JS, Ribeiro CT, Filho PRC, Pissinatti A, Flausino W, Lopes CWG. Infection by Toxoplasma gondii in neotropical non-human primates. Pesq Vet Bras 2012; 32(10): 1041-1044. http://dx.doi.org/10.1590/S0100-736X2012001000017.

Robert-Gangneux F, Dardé ML. Epidemiology of and diagnostic strategies for toxoplasmosis. Clin Microbiol Rev 2012; 25(2): 264296. http://dx.doi.org/10.1128/CMR.05013-11. PMid:22491772.

Souza CO, Tashima NT, da Silva MA, Tumitan ARP. Cross-sectional study on toxoplasmosis among female students on a university course in the Presidente Prudente region, State of São Paulo. Rev Soc Bras Med Trop 2010; 43(1): 59-61. http://dx.doi.org/10.1590/ S0037-86822010000100013. PMid:20305970.

Tenter AM, Heckeroth AR, Weiss LM. Toxoplasma gondii: from animal to humans. Int J Parasito/ 2000; 30(12-13): 1217-1258. http:// dx.doi.org/10.1016/S0020-7519(00)00124-7. PMid:11113252.

Tidy A, Fangueiro S, Dubey JP, Cardoso L, Lopes AP. Seroepidemiology and risk assessment of Toxoplasma gondii infection in captive wild birds and mammals in two zoos in the North of Portugal. Vet Parasitol 2017; 235: 47-52. http://dx.doi.org/10.1016/j. vetpar.2017.01.004. PMid:28215867. 